\title{
Development of a web management system for the internship process at the TecNM campus Lerdo
}

\section{Desarrollo del sistema web para la gestión del proceso de residencia del TecNM campus Lerdo}

\author{
RODRÍGUEZ-LOZANO, Karla Verónica†*, MORENO-NÚÑEZ, Elda, ARZOLA-MONREAL, Juan \\ Martín and FLORES-LUÉVANOS, María Guadalupe
}

Tecnológico Nacional de México Campus Lerdo / Instituto Tecnológico Superior de Lerdo

ID $1^{\text {st }}$ Author: Karla Verónica, Rodríguez-Lozano / ORC ID: 0000-0003-2832-4165, CVU CONACYT ID: 355351

ID $1^{\text {st }}$ Co-author: Elda, Moreno-Núñez / ORC ID: 0000-0002-5912-082, CVU CONACYT ID: 654015

ID $2^{\text {nd }}$ Co-author: Juan Martín, Arzola-Monreal/ ORC ID: 0000-0002-5829-7818, CVU CONACYT ID: 428245

ID $3^{\text {rd }}$ Co-author: María Guadalupe, Flores-Luévanos / ORC ID: 0000-0003-2613-1431, CVU CONACYT ID: 450310

DOI: $10.35429 / \mathrm{JOCT} .2021 .15 .5 .1 .10$

Received March 15, 2021; Accepted June 30, 2021

\begin{abstract}
The TecNM campus Lerdo is developing a Web Based System for the Management of the Residence Procedures (SIGEPRORE), in order to adhere to the ISO 9001:2015, which this institution of higher education currently operates under, for which it is necessary to automate the current professional residency quality management system. SIGEPRORE is an institutional software package designed to support all those involved in the professional residency procedure. It has a new and improved web design, which allows the integration of new modules, functionalities, and technological tools for increased user optimization. Participants in this project are students from the engineering degree in computer systems of the ITSL and professors' part of the academic body in consolidation "Software engineering applied to solutions". The agile methodology used as a guideline to develop the project was the SCRUM. The impact of the project is of great relevance as it is intended to establish a web system which will contain all the operating policies of the professional residence and quality management system.
\end{abstract}

Development, Software, Intership

\section{Resumen}

El TecNM campus Lerdo está desarrollando un Sistema Web para la Gestión del Proceso de Residencia (SIGEPRORE), con el fin de adherirse a la ISO 9001:2015, bajo la cual actualmente opera esta institución de educación superior, para lo que es necesario automatizar el actual sistema de gestión de la calidad de la residencia profesional. SIGEPRORE es un software institucional diseñado para apoyar a todos los involucrados en el trámite de residencia profesional. Cuenta con un nuevo y mejorado diseño web, que permite la integración de nuevos módulos, funcionalidades y herramientas tecnológicas para una mayor optimización del usuario. Los participantes en este proyecto son estudiantes de Ingeniería en Sistemas Computacionales del ITSL y los profesores pertenecientes al cuerpo académico en consolidación "Ingeniería de software aplicada a soluciones". La metodología ágil que se utilizó como guía para desarrollar el proyecto fue SCRUM. El impacto del proyecto es de gran relevancia ya que se pretende establecer un sistema web que contendrá todas las políticas operativas de la residencia profesional y el sistema de gestión de la calidad.

Desarrollo, Software, Práctica profesional

Citation: RODRÍGUEZ-LOZANO, Karla Verónica, MORENO-NÚÑEZ, Elda, ARZOLA-MONREAL, Juan Martín and FLORES-LUÉVANOS, María Guadalupe. Development of a web management system for the internship process at the TecNM campus Lerdo. Journal of Computational Technologies. 2021. 5-15:1-10

\footnotetext{
* Author Correspondence: (e-mail: karla.rl@itslerdo.edu.mx)

$\dagger$ Researcher contributing as first author.
} 


\section{Introduction}

Since 2006, the Instituto Tecnológico Superior de Lerdo has a quality management system, which is currently based on the ISO 9001: 2015 standard. This system is a model that allows to provide a quality educational service to students, and ranges from admission to graduation, strengthened with the process of linking.

The quality policy is to provide a service based on the Educational Model of the Tecnológico Nacional de México (TecNM) supported by a Quality Management System, for the satisfaction of its customers, continuous improvement and risk analysis according to the ISO 9001:2015 Standard.

The professional internship is an educational strategy of a curricular nature, which allows the student to undertake a theoreticalpractical, analytical, reflective, critical and professional project; with the purpose of solving a specific problem of the social and productive reality, to strengthen and apply their professional skills.

As part of the quality management system, the TecNM campus Lerdo has a procedure for the management of the professional internship process, this procedure applies to all the study programs of the careers at the undergraduate level of the Instituto Tecnológico Superior de Lerdo in schooled modality, not schooled, distance schooling and mixed, there are four main actors within this process: Student, Linking Department, Academic Division and Internal Advisor.

The flow of the procedure is as follows, the academic division conducts an informative session, the student requests the cover letter to the Linking Department, which delivers it, the student seeks and manages the place and prepares a preliminary report, the academic division receives, reviews and authorizes the report, and if it is correct, assigns the internal advisor, the student develops the project and the internal advisor follows up, evaluates and issues a grade, finally the academic division receives the report of the finished project.
The quality management policy is based on the educational model of the Tecnológico Nacional de México, so this procedure is governed by the guidelines for the operation and accreditation of the professional internship defined in the Manual of AcademicAdministrative Guidelines of the Tecnológico Nacional de México, in which all the operating policies of the actors of this process are defined, as well as the evaluation formats that advisors use to measure the intern's performance and evaluate the final report. As a tool to support this process, an internal software has been developed to automate the professional internship procedure belonging to the quality management system based on ISO 9001:2015 that currently operates in this institute.

The objective of the project is to implement a web system for the management of the professional internship process of the TecNM Lerdo campus. Version 1.0 of the Internship Procedure Management System (SIGEPRORE) was released in January 2020. A year after its intensive use, derived from the Covid-19 pandemic, it has identified the need for improvements in its web design, integration of new modules with more functionalities for heads of divisions, academic director and advisors, as well as the use of technological tools that allow users to use a web system for the management of the professional internship process.

This technological development aims at the implementation of the Web System, based on all the features mentioned before, and adapting to the virtual way of working of all the staff and students involved in the process during the COVID-19 pandemic. The methodology proposed for this project is the SCRUM whose main objective is the fulfillment of expectations, flexibility to changes, time reduction and higher quality of the software.

For the construction of the web system, the $\mathrm{PHP}{ }^{\circledR}$ programming language is implemented, which allows the creation of dynamic web pages and the development of server-side scripts, with the MySQL database manager for the programming of stored procedures that interact with web pages. The presentation of a website is an important factor that contributes to its usability. To achieve a simple and pleasing design to the end user, Bootstrap $\odot$ is used. 
This article describes the process of an applied research, which aimed to develop a Web System for the Management of the Internship Procedure of the TecNM campus Lerdo. The technical part details the methodology, the technological software tools that were used and the results obtained.

\section{Methodology}

Sommerville (2011) states that engineering consists of selecting the most appropriate method for a set of circumstances; To produce quality software, you need to choose a strategy that orders development activities and adapts to your team's context. The perspective of agile development recommends in the first instance the formation of a good team, which creates its own production environment, to facilitate the adoption of a methodology with this approach, since agile methods are more effective when the system manages to be designed with a small assigned team that communicates informally. "Agile methods are incremental development methods that focus on fast design, frequent software releases, reduced process expenses, and high-quality code production. They involve the customer directly in the development process" (Sommerville, 2011)

The internship process management system (SIGEPRORE) in its versions 1.0 and 2.0 has been developed under the responsibility of a team of less than 10 people, in which the interaction between the members and the fast development of small functionalities is privileged, freeing the end users for their test, in order to obtain feedback in the short term; when a problem has been reported, all team members contribute to the solution and one or two developers take care of its implementation, without affecting the development process.

Therefore, we have opted for the formal adoption of an agile method as a reference framework for project management specifically SCRUM, characterized by three phases: the first is the planning of the project and the design of the software architecture; the second, a series of sprint cycles and finally the conclusion phase of the project. The main feature of this method lies in the second phase, being the sprint cycles planning units delimited in time, in which they select the specifications to be developed, the increment is implemented to the system, and it is released to the participants. (Trigas, 2012)
The design of the software architecture was carried out by the project leader "SCRUM master", based on the needs expressed by the clients of the application and the contributions of the SCRUM developers of the project. The architecture is represented by class diagrams, which are part of the static modeling of the system.

In the design of the particularities that would be developed in each sprint, the modeling of the use cases has been a valuable tool that has contributed to the communication within the development team and with the users of the system.

The use cases provide insight from the customer's point of view, they are based on functional requirements, and do not capture the details of their implementation (Jacobson et al, 2013).

Figures 1 to 4 present the project's use case diagrams; Figure 1 shows the functions associated with the division chief, who can use the system to assign residents to advisors, view meeting logs, and download evaluation reports. $\mathrm{He}$ or she can also change his or her own password and watch a video tutorial of the system use.

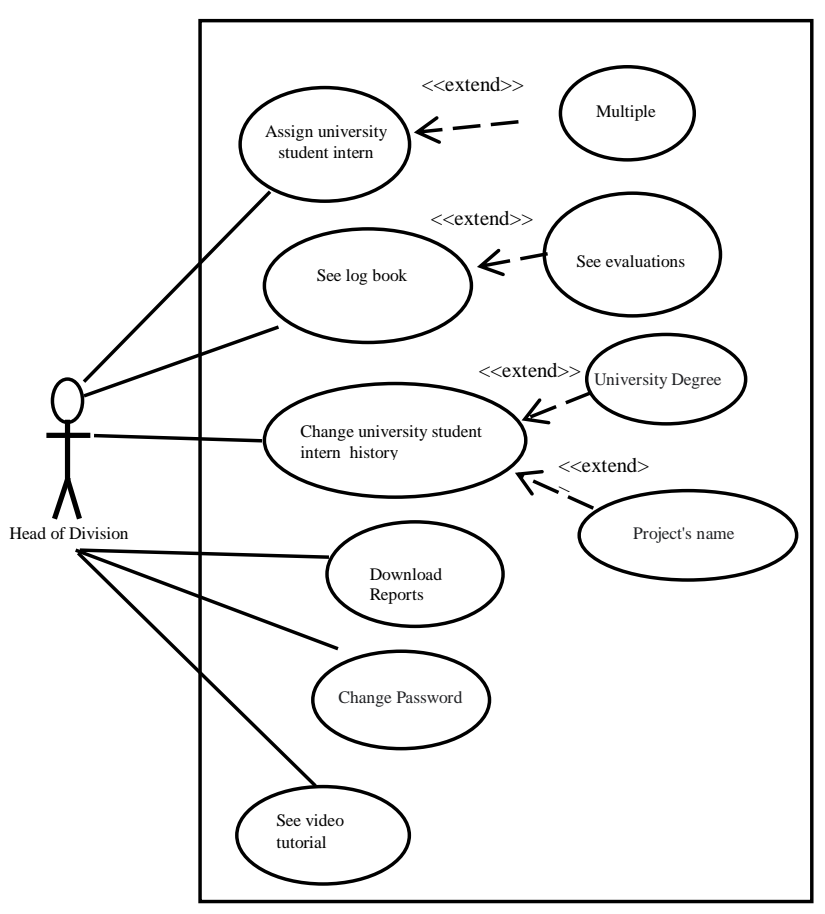

Figure 1 Diagram of division chief's use cases Source: Own Elaboration 
Figure 2 shows the use cases of the academic director, who through the system can view the data of the professional internships, the logs of the meetings and validate the titles of the projects; it also has a video tutorial of the system use.

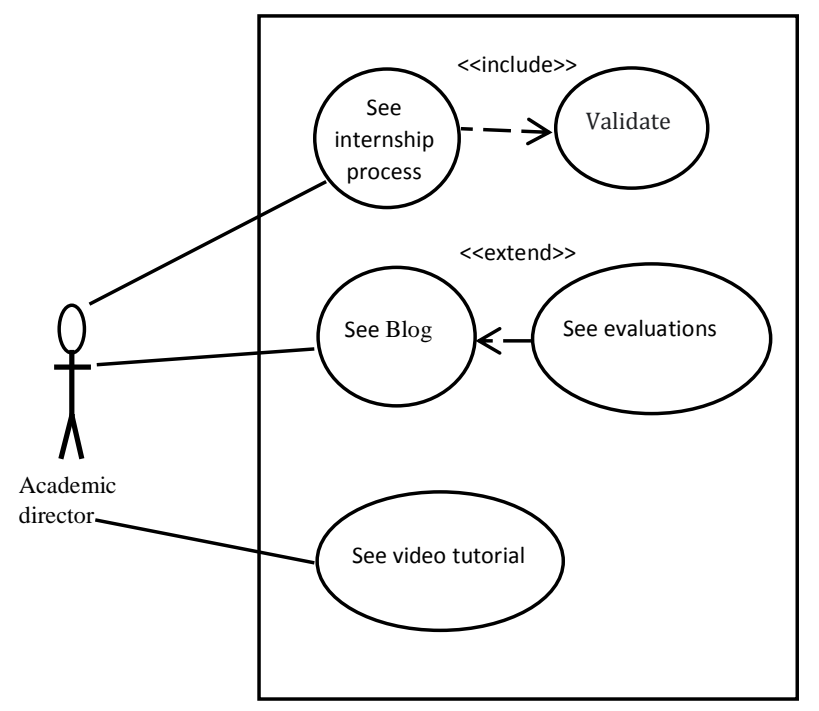

Figure 2 Academic director use case diagram Source: Own Elaboration

Figure 3 shows the use cases associated with the internal advisor, who is the teacher assigned to follow up on the professional intern's project. The advisor is in charge of registering the data of the internship such as the name of the project, company, among others. It also records the logs of the meetings with the intern, makes the evaluations and downloads the reports.

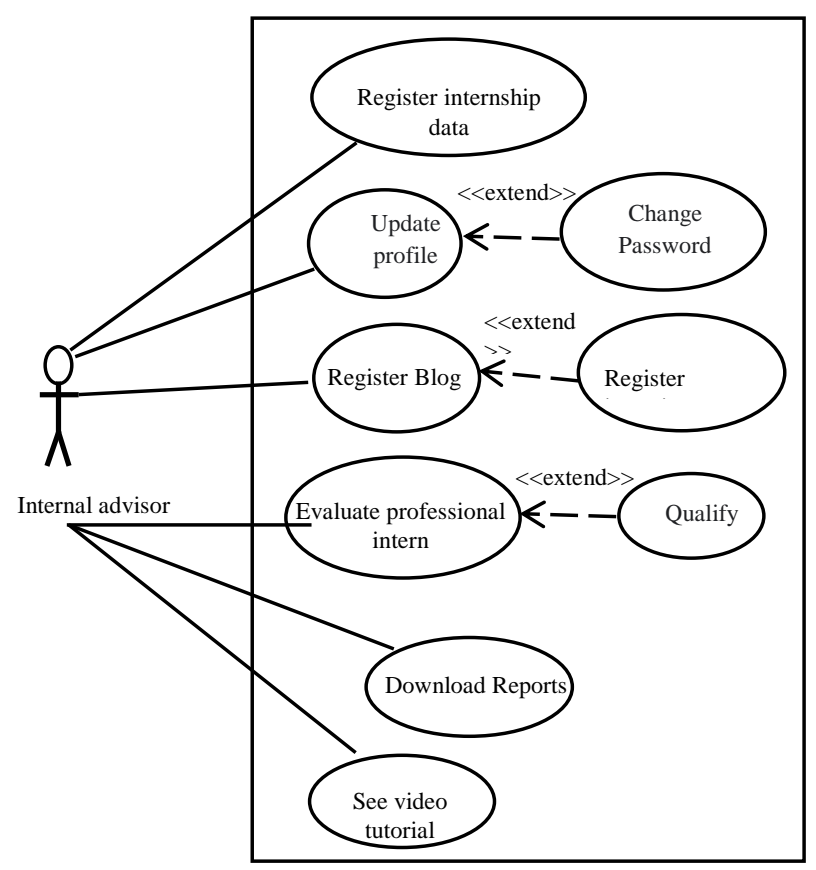

Figure 3. Diagram of internal advisor use cases Source: Own Elaboration
Figure 4 shows the functions associated with the professional intern, who uses the system to view his or her project data and read the logs of advisory meetings. They can also modify their password to access SIGEPRORE and watch a video tutorial of its use.

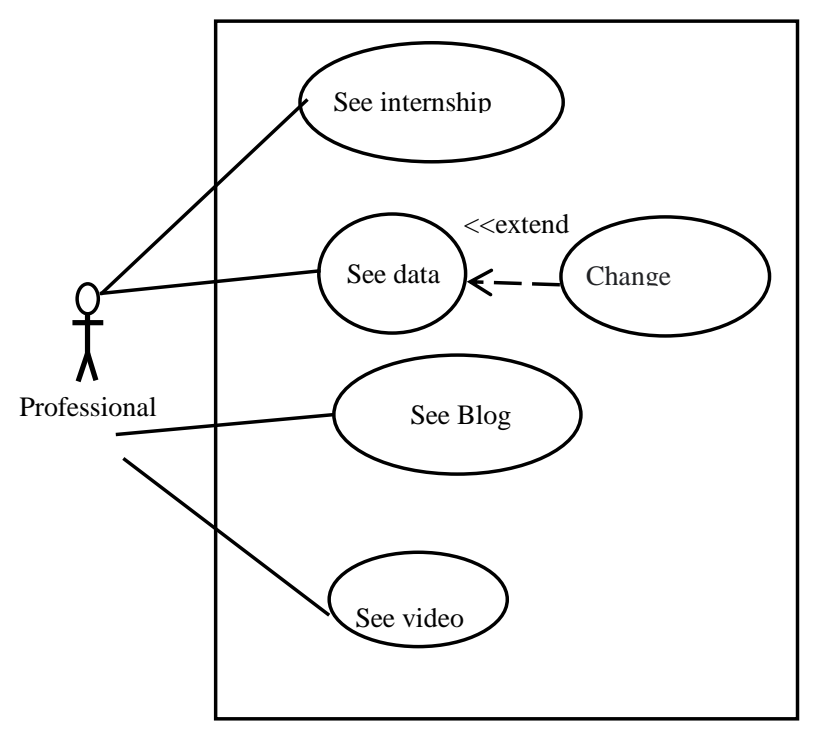

Figure 4. Diagram of professional intern use cases. Source Own Elaboration

\section{Construction of modules}

Salazar (2009) It provides that the construction of software in modules is based on the aspects in which the designer pays greater attention such as functionality and attractiveness; coupled with the objective of building a site with clear, interesting information and an appropriate vocabulary for the user, in order to achieve an economic benefit or recognition for the owner of the site.

\section{Results}

SIGEPRORE, has two versions since its publication, Version 1.0 in 2020 and Version 2.0 in 2021. Version 2.0 of the system consists of five modules, 1) Head of Division, 2) External Advisor, 3) Internal Advisor, 4) Intern and 5) Academic Director. The system groups the uses already described in a modular way; each actor interacts with its module. Figure 5 lists the functionalities of each module. 
Head of Division

- Assign interns to the internal advisor in a unitary and/or multiple way. The system will inform users and proceed to send mail with access instructions.

- Accept project's name.

- Change the name of the project and the internal advisor on extemporaneous dates.

- Monitor the progress of the intern through the log and the evaluations generated by the advisors.

- Download the reports defined in the quality guideline.

- View the history of interns to update the status of their degree.

\section{Internal Advisor}

- Edit data of the internship, such as name of the project, day, time and place of the tutoring, name of the company and sector to which it belongs.

- Add the company's external advisor. The system will register the

user and proceed to send an email with access instructions.

- Follow up with the intern, fill out the log weekly.

- Evaluate intern according to the guidelines of the TECNM.

- Conduct an interview with the external advisor, which will be displayed in the system.

- Download Report

Academic Director
- Accept project's name.
- Monitor the intern's progress through the log and the evaluations
generated by the dvisors.
- See log book.
- See evaluations.

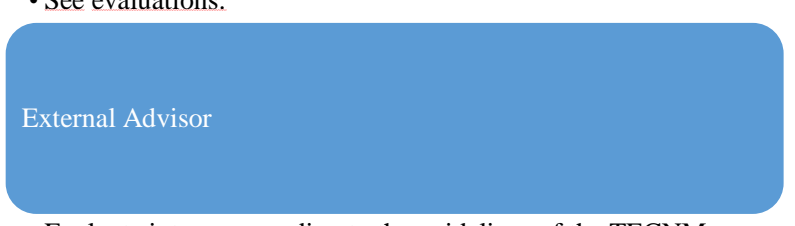

- Evaluate interns according to the guidelines of the TECNM

- Observe the follow-up log.

- Download reports

\section{Intern}

- To Know the general data of the internship and its tracking log.

Figure 5. Description of Functionalities

Source: Own Elaboration

In order to store and manipulate the data, the MySQL® management system was used. The Entity-Relationship model of the database is formed by 12 tables, one of them is the internship table, which stores all the data of the professional internship; this table is related to other entities corresponding to the different actors of the system. The criteria tables, evaluation and detailed evaluation, are used to manage the evaluation process by the intern's advisors.
To keep track of the weekly follow-up to the intern and the interviews that are carried out to the external advisor, the advisory and interview tables were defined. The table that was incorporated in version 2.0, is the intern's history table, in it all the historical data of internship will be stored to generate statistical reports. The database is also composed of five triggers and five stored procedures, which carry out the actions to save the information.

Figure 6 shows this relational model including only the name of the entities that make up this diagram.

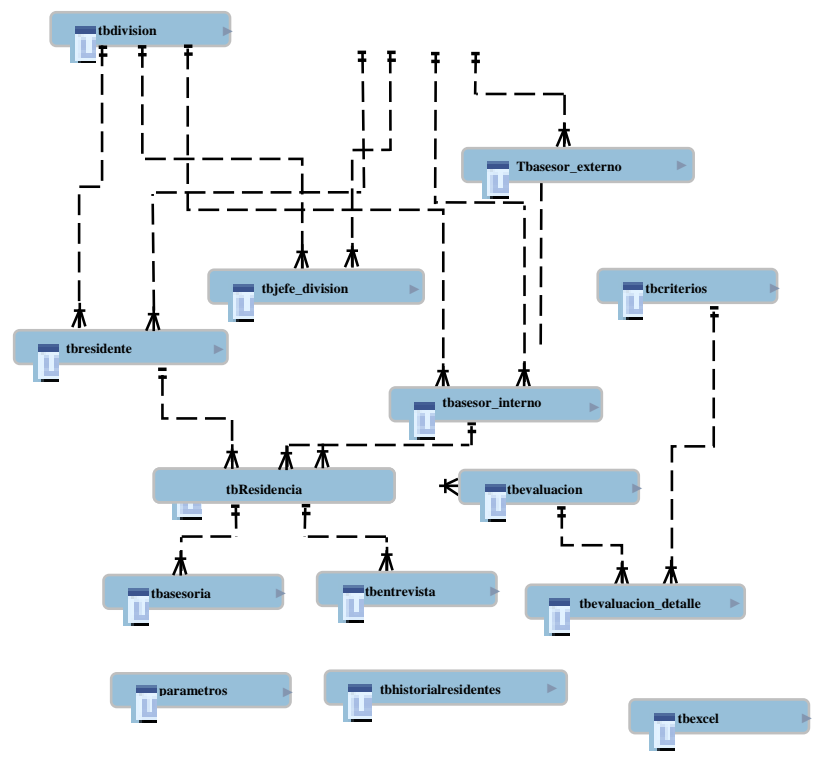

Figure 6. Entity Model - SIGEPRORE Relationship 2.0 Source: Own Elaboration

\section{Head of Division Module}

The head of division can access the internship section (figure 7), here is the information about the internship such as: Control number, name, date of advice, internal advisor, progress, accepted name, log, as well as whether or not the name of the project was already accepted by the academic director.

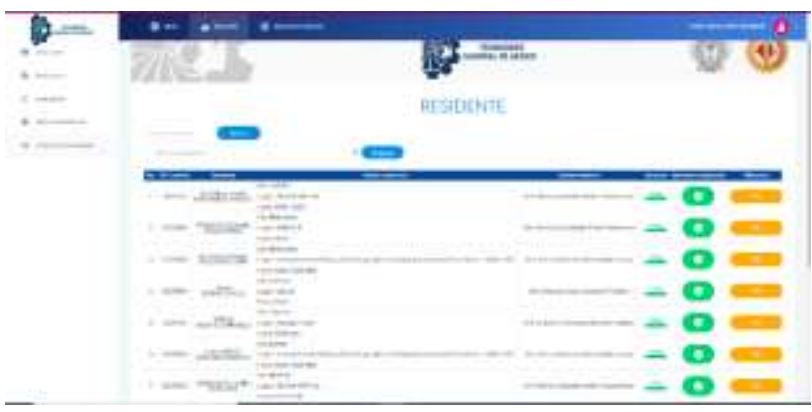

Figure 7 GUI Internship SIGEPRORE 2.0

RODRÍGUEZ-LOZANO, Karla Verónica, MORENO-NÚÑEZ, Elda, ARZOLA-MONREAL, Juan Martín and FLORES-LUÉVANOS, María Guadalupe. Development of a web management system for the internship process at the TecNM campus Lerdo. Journal of Computational Technologies. 2021 
In order to assign interns to internal advisers, it is necessary to know that students are already enrolled in the subject of professional internship. This process is performed automatically by the system through an API that connects the software to the institution's server. The process consists of the system sending the id of each career, this data is sent by means of POST to a server, which will process and send a response to the application using JSON notation, if the id of the career exists, the API returns all the students enrolled to internship and the system will proceed to save this information in their respective tables using a stored procedure. The assignment of interns can be done in two ways, the first is that for each intern is assigned an internal advisor, and the second is that for each internal advisor several interns are assigned, these processes are defined as simple assignment and multiple assignment respectively. Figures 8 and 9 show these assignments.

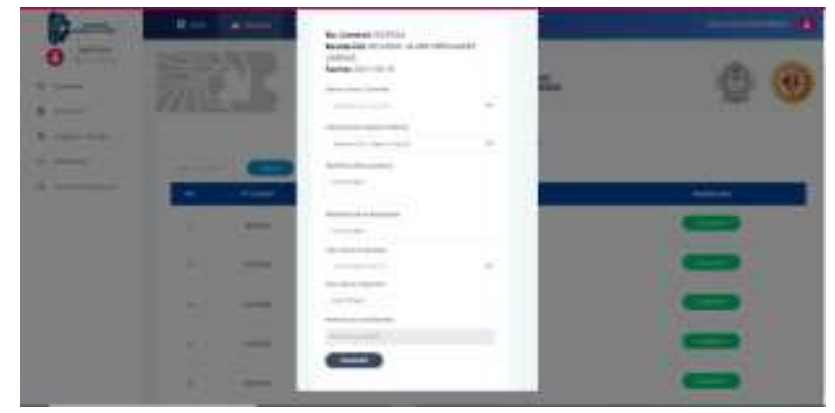

Figure 8 GUI. Simple assignment SIGEPRORE 2.0

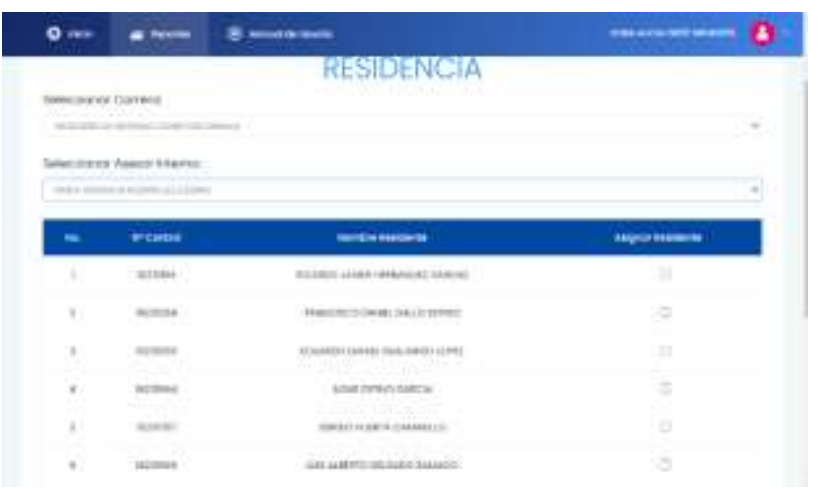

Figure 9 GUI. multiple assignment SIGEPRORE 2.0

The head of division will be able to view the internal adviser's logbook and will be able to add comments. (Figure 10)

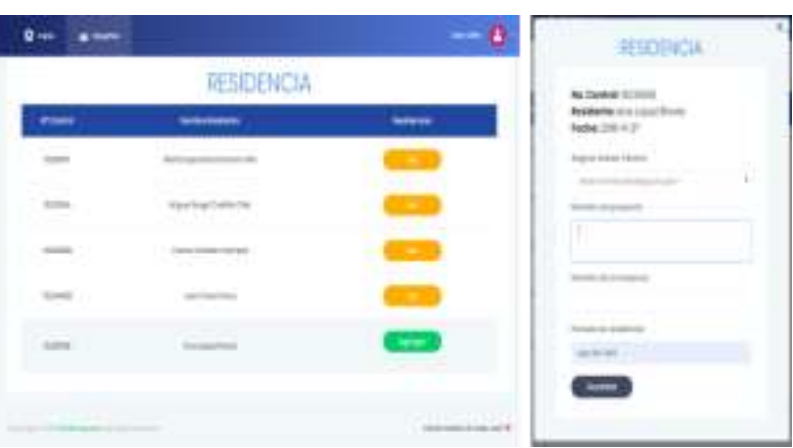

Figure 10 GUI. Blog SIGEPRORE 2.0

The system allows the head of division to download all the reports that the system generates according to the procedure and the guideline. Figure 11.

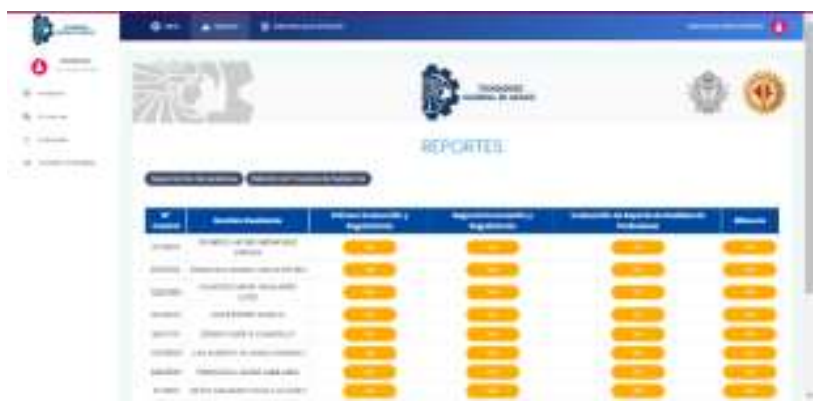

Figure 11 GUI. Reports SIGEPRORE 2.0

In the intern history section, the data of the interns already graduated is shown as the control number, name of the intern, semester, grades, period of internship, internal advisor, degree, information. etc. Filters can be applied to speed up the search for information and you can generate graphical reports of the internship history. Figure 12 shows an example of a chart.

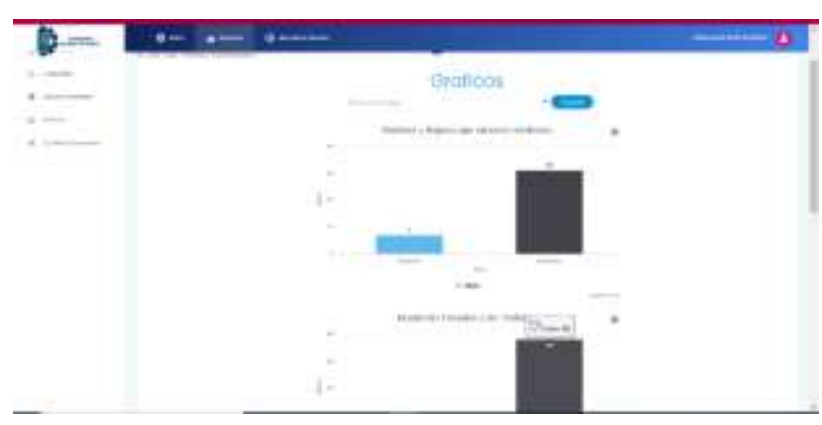

Figure 12 GUI. Graphics SIGEPRORE 2.0

In figure 13 , it is observed how the head of the division will be able to control the status of the graduate's degree process, selecting the option of accrediting a degree in case this procedure is concluded. 


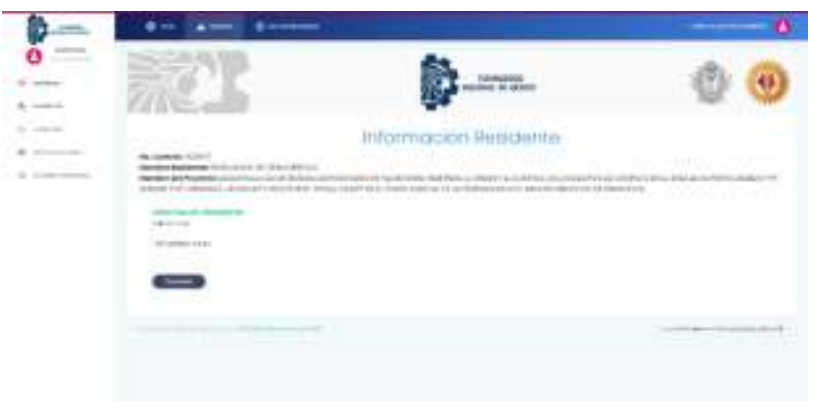

Figure 13 GUI. Obtained degree SIGEPRORE 2.0

\section{Internal advisor}

In the internship section, which is shown in Figure 14, the data of the internships are observed as: control number, intern's name, project's name, company's name and status of the name of the project.

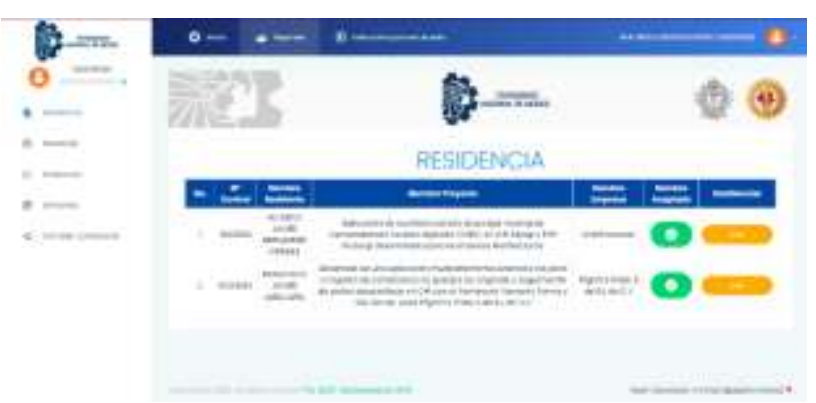

Figure 14 GUI. Internship SIGEPRORE 2.0

The internal advisor will be able to see the percentage of progress of the project, to later give the follow-up through the log. Figures 15 and 16 show it.

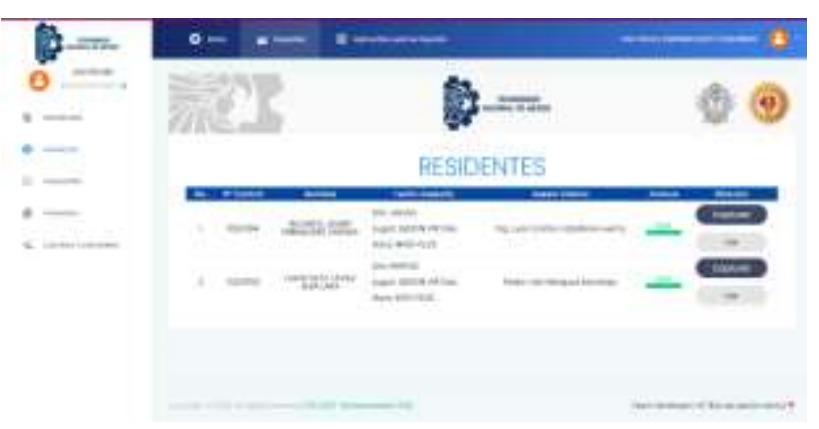

Figure 15 GUI. Internship SIGEPRORE 2.0

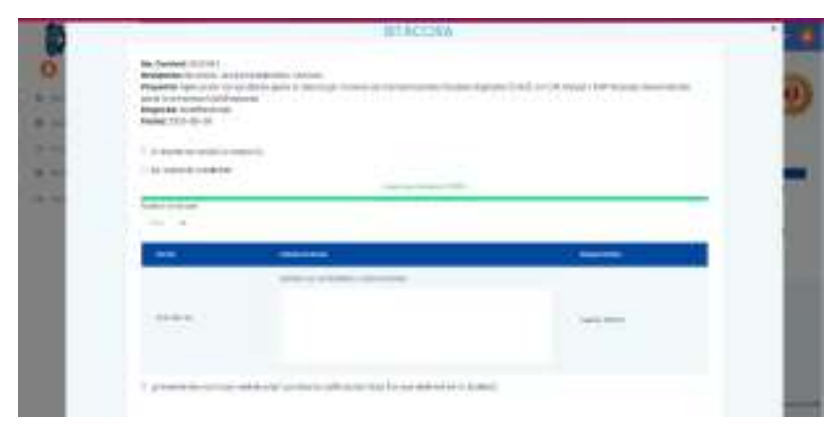

Figure 16 GUI. Blog SIGEPRORE 2.0
The internal advisor can view and edit the general data of the internship and add the external advisor of the company. The system will register the user and proceed to send an email with access indications.

The internal advisor performs two intern's evaluations and a final evaluation of the report, these evaluations take into account the criteria defined in the TECNM guidelines manual. Figure 17 shows these evaluations.

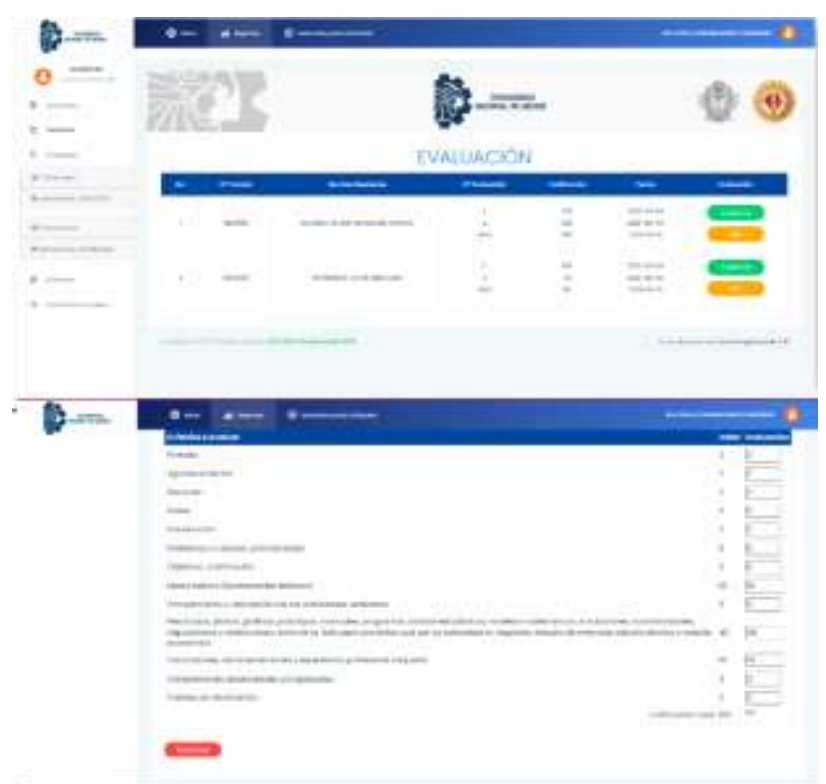

Figure 17 GUI. Evaluation SIGEPRORE 2.0

The internal advisor also conducts the necessary interviews, capturing the interviewee's name and observations, as shown in the figure below.

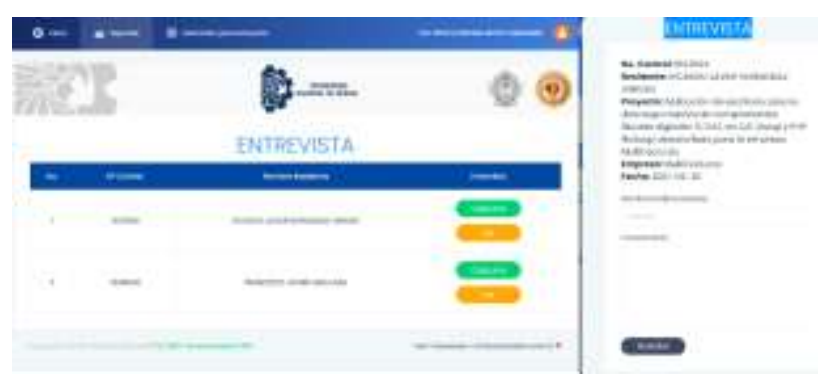

Figure 18 GUI. Interview SIGEPRORE 2.0

The advisor will be able to view the evaluations and the log, through PDF reports as shown in Figure 19. 

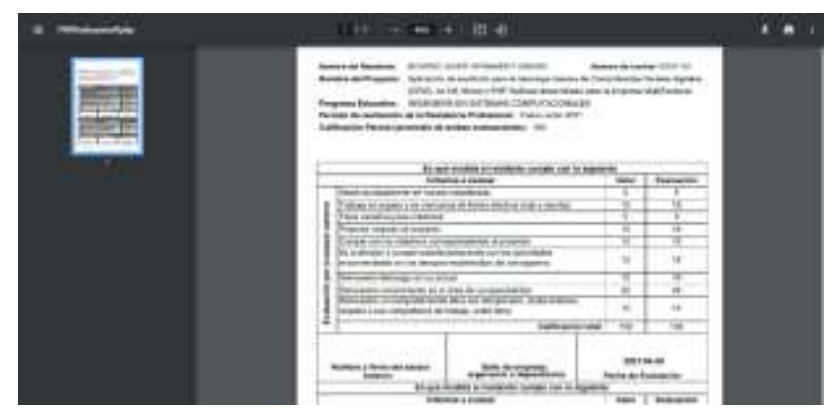

Figure 19 GUI. Evaluation Report SIGEPRORE 2.0

\section{Academic Director}

Figure 20 shows the interface, where the intern's data is shown, such as the control number, the intern's name, division, project progress and $\log$ and he or she can search for the interns by career and / or internal advisor.

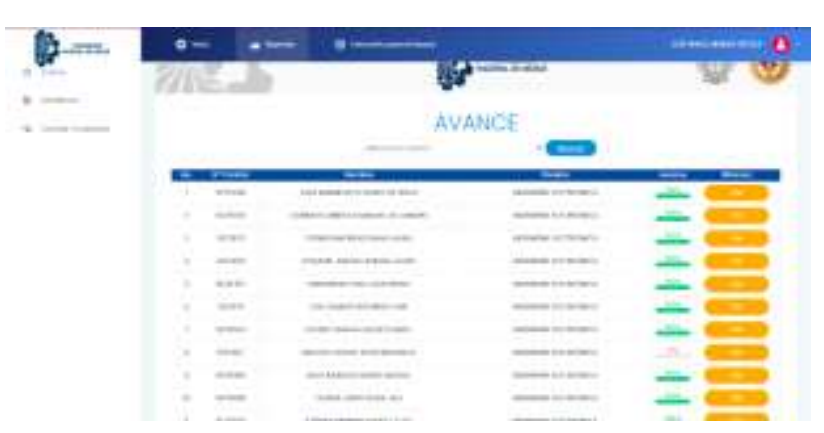

Figure 20 GUI. Progress SIGEPRORE 2.0

Among the new functionalities, there is the process that the academic director performs for the acceptance of the name of the project, this point is important, because as long as the name is not accepted, the information cannot be sent to the school services department, to generate the forms. The internal advisor will be in charge of modifying the name until it is accepted. Figure 21 shows the name acceptance process.

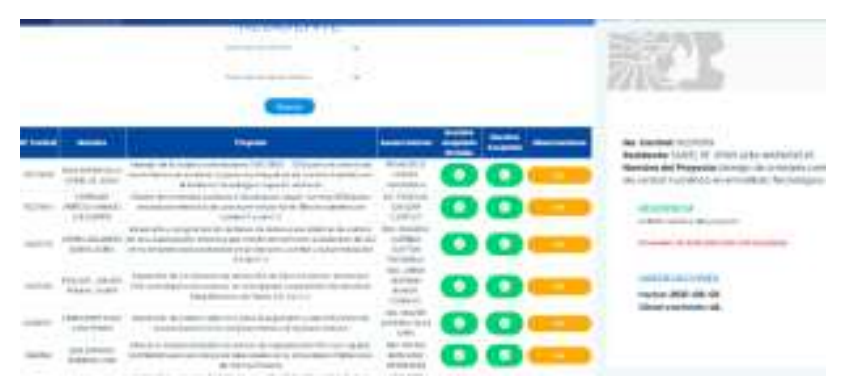

Figure 21. GUI. Accepts name SIGEPRORE 2.0

\section{External Advisor}

The external advisor will be able to edit profile, see the progress and the follow-up log that the internal advisor fills, he will also be able to make his two evaluations, update them and view them in PDF document. Figures 22, 23 and 24 show some of these processes.

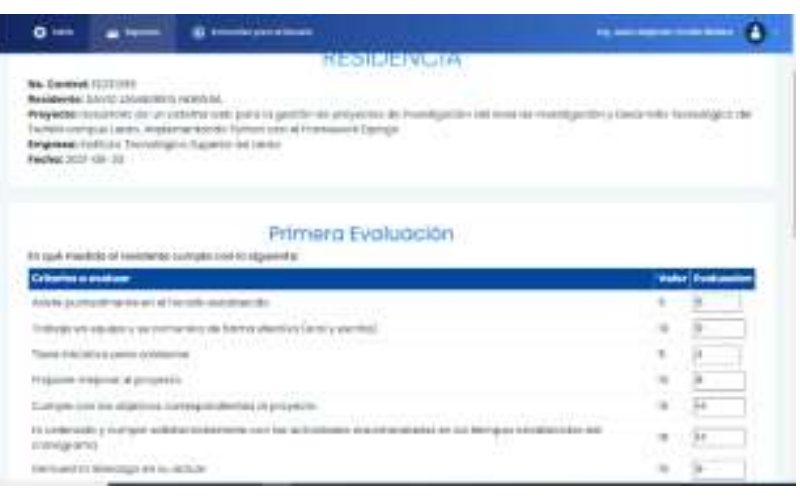

Figure 22 GUI Evaluation SIGEPRORE 2.0

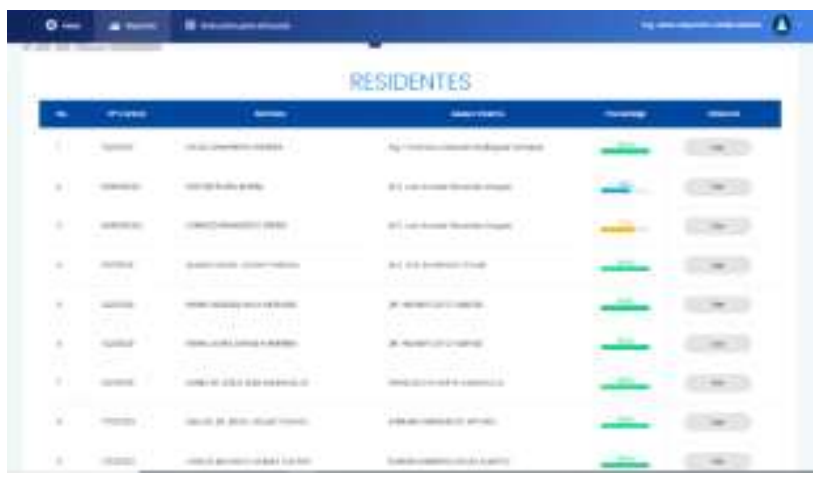

Figure 23 GUI. progress SIGEPRORE 2.0

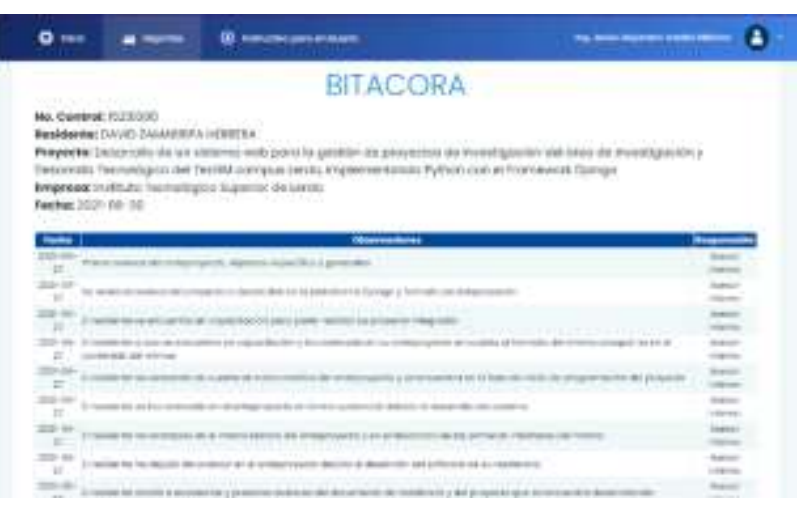

Figure 24 GUI. Blog SIGEPRORE 2.0

\section{Quality assurance}

In the tests carried out in SIGEPRORE 1.0, syntactic, design and some process errors were identified in the modules of Internal Advisor, External Advisor, Administrator, Head of Division and Intern. 
By being released early, the development team managed to complete the changes quickly and efficiently to be used, as well as resolve the errors that arose when using the SIGEPRORE 1.0 system.

In the SIGEPRORE 2.0 system, the activities carried out during the internship process were complemented and facilitated and the desired requests for the SIGEPRORE 2.0 version were fulfilled.

The following were added:

- $\quad$ Security: users will be able to change the password of their login to the system and control access to their profile, as well as protect the data that is generated and used in the system processes by encrypting the user's passwords in the database.

- Control: users will be able to keep track of the data with the generation of reports in PDF and Excel according to their type of user and privileges within the system.

- Restrictions: the system has restrictions to access information, make changes or delete some data, depending on the type of user and module to which it is entered. The system has deadlines for renaming the project and updating assessments.

Access: the head of division will always have access to change the name of the internship project and change the internal advisors.

- Functionality: the system has all the processes that are carried out in the period of internship in an accessible way.

- Video tutorials were created for the understanding of usability and processes that are performed within the system.

- Practical: the system generates a practical way to carry out the entire internship process in a simple way.

It generates searches of interns by their control number.

Filters information when selecting a desired career.

For division heads, an optimal way was generated by assigning internal advisors and creating internships.

- Decrease in Time: the time in the search for the information of the interns is reduced.
- $\quad$ New module: the Academic Director's module is generated, where there is access to all active interns in internships, accept the names of the internship projects, make observations and obtain reports.

- Satisfaction: the system is a tool of great help to users, to work remotely the processes that must be carried out in the professional intership, during the health contingency due to Covid-19.

\section{Display}

The website was set on a server and is currently used by approximately 200 users every semester. The URL of the website is http://sigeprore.itslerdo.edu.mx/. Figure 25 shows the main screen of the site.

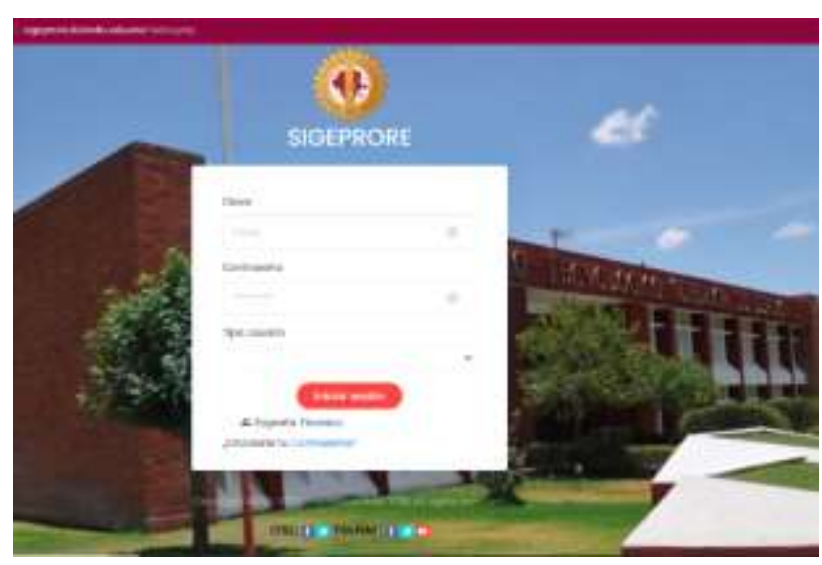

Figure 25 GUI. Index SIGEPRORE 2.0

\section{Acknowledment}

We thank the Tecnológico Nacional de México, the Government of the State of Durango, and the Instituto Tecnológico Superior de Lerdo for having financed this project; as well as the person in charge of the Professional internship procedure in the Quality Management system, Dora Ortiz Sifuentes and all the students who have been part of this project.

\section{Conclusions}

The importance of updating an institutional procedure with elements that allow optimizing and streamlining most of its activities is undoubtedly an aspect that improves the overall efficiency of this higher education institution. 
The most relevant result of the elaboration of this project is that this system will be established in the operating policies of the professional internship procedure of the ITSL quality management system.

Another result is that all the tasks of the professional internship procedure that are carried out in a presence way, it is possible to perform them remotely, asynchronously and agilely; optimizing tasks, from the initial phase of the procedure with the generation of the project data, to the culmination of this process with the generation of the final reports.

The different stakeholders of the project obtain significant improvements, mainly in the organization and time dedicated to the tasks related to their respective profiles.

The improvement that can be seen from the above, it is that, it is possible to develop a system that in addition to running in a web environment, it is adapted for the main mobile platforms, in order to extend the operational range of a procedure of vital importance such as profesional internship.

\section{References}

Axarnet. (31 de Octubre de 2017). Bootstrap¿Qué es y Cómo funciona? Obtenido de Axarnet: https://www.axarnet.es/blog/bootstrap/

Beati, H. (2011). PHP Creación de páginas Web dinámicas. Buenos Aires: Alfaomega.

Gauchat, J. D. (2012). El gran libro de HTML5, CSS3 y Javascript. Marcombo. Barcelona.

Jacobson, I., Spence, I., Bittner, K., Salazar, C. L. A. \& Zapata J.C. M. (2013). Casos de uso 2.0. La guía para ser exitoso con los casos de uso. Ivar Jacobson International S.A.

Pressman, R. S. (2011). Ingeniería del software. Un enfoque práctico. 7a edición Mc Graw Hill. México

Salazar Z. J. E., \& Puentes A. O. (2009). Modulo Diseños de Sitios Web. UNAD. La plata, Huila Obtenido de wordpress.com: https://trabajodise.files.wordpress.com/2013/05/ 301122.pdf
Sommerville, I. (2011). Ingeniería de Software 9a Edición. Pearson Educación. México

Spona, H. (2010). Programación de bases de datos con MYSQL y PHP. Marcombo.

Trigas G. M. (2012). Metodología SCRUM. Obtenido de http://openaccess.uoc.edu/webapps/o2/bitstrea $\mathrm{m} / 10609 / 17885 / 1 / \mathrm{mtrigas}$ TFC0612memoria.pd f

Guijarro, Á. P. (2012). Protocolo HTTP. Obtenido de https://alvaroprimoguijarro.files.wordpress.com /2012/01/ud04_http_alvaroprimoguijarro.pdf

JSON. (s.f.). Introducción al JSON. Obtenido de JSON: https://www.json.org/json-es.html

PHP. (2019). Introducción PDO. Obtenido de PHP:

https://www.php.net/manual/es/intro.pdo.php

Tecnológico Nacional de México (2015). Manual de Lineamientos AcadémicoAdministrativos del Tecnológico Nacional de México

Zúñiga, J. E., \& Andrade, O. P. (10 de Diciembre de 2009). Modulo Diseños de Sitios Web. Obtenido de wordpress.vcom: https://trabajodise.files.wordpress.com/2013/05/ 301122.pdf 